\section{Fundamentalist Signals in Volatility Scenarios: Evidence in the Brazilian Stock Market}

\author{
Edson Bastos ${ }^{1}$ \\ engenheiroedsonbastos@gmail.com | (100000-0002-6948-6390 \\ Patricia Bortolon ${ }^{2}$ \\ patricia.bortolon@ufes.br | (D)0000-0001-8087-3837 \\ Vinicius Maia ${ }^{1}$ \\ viniciusmothemaia@gmail.com | (DD0000-0001-6156-3104
}

\begin{abstract}
This article investigates whether the usefulness of fundamentalist signals to predict returns are altered in context of high volatility and also considering the sensitivity of assets to the IVol-BR volatility index. In times of high volatility, investors could make their decisions based on risk aversion and not only on the fundamentals signals of companies. In addition, it is possible to see how different delays in fundamentalist signals are related to future returns. The methodological choice is for estimators in panel data for the analysis of non-financial companies that have shares traded on B3 - Brasil, Bolsa, Balcão - in the period from 2011.3Q to 2018.2Q. The results show evidence of changes in the explanatory capacity of fundamentalist signals in different volatility scenarios, and for different sensitivities to IVol-BR. This finding may impact the decision-making of managers and investors as it enables the design of investment strategies based on fundamentalist signals adhering to different risk scenarios.
\end{abstract}

\section{KEYWORDS}

Fundamental analysis, Accounting indicators, Volatility, Fusion methods
${ }^{1}$ Universidade Federal do Rio de Janeiro, Rio de Janeiro, RJ, Brasil

${ }^{2}$ Universidade Federal do Espírito Santo, Vitória, ES, Brasil

Received: 03/26/2019.

Revised: 07/26/2019.

Accepted: 03/26/2020.

Published Online: 10/05/2020

DOI: http://dx.doi.org/10.15728/bbr.2020.17.6.2 


\section{INTRODUCTION}

The driving force of this research arises from questioning the usefulness of fundamentalist analysis, built from accounting variables, addressed here together with market volatility, which is considered a proxy for phenomena outside the entity, as it is observed that stocks prices are impacted by exogenous factors, such as electoral speculation, political and war conflicts, and exchange rate fluctuations.

Thus, it is observed that the share price does not reflect in an exclusive, integral, and immediate way for all the informative content of the accounting indicators. And it is precisely in this gap that the exploration of the divergence in pricing converges with fundamentalist analysis, as it is another path to be followed by investors in order to achieve their primary objective: to maximize the return on their investments. Therefore, the objective of the research is to find out how the fundamentalist signals are related to the return in different volatility scenarios.

Given that not only accounting variables have an explanatory capacity on returns, the presence of exogenous factors can interfere with the performance obtained from econometric modeling for forecast returns. In the literature, such factors are known as external shocks and can lead to mistaken conclusions regarding the true impact of the signs on the dependent variable. For example, changes in the perception of market risk can impact the return of the asset independently and externally to the influence of the signals under study, so it is important that external interference is controlled.

For Vicente and Guedes (2010) the implied volatility concentrates investors' expectations, plus a risk premium. If such a premium is constant over time, it will be a good estimator of the asset's volatility. Still according to Vicente and Guedes (2010), the implied volatility has shown promising results for forecasting future volatility. The Volatility Index of the Brazilian stock market (IVol-BR) is based on the implied volatility, so this indicator can be seen as a proxy for stock risk.

In the particular case of the Brazilian market, Astorino, Chague, Giovannetti and Silva (2017) demonstrated that IVol-BR has significant predictive power on the future volatility of the return, so it is possible to use the volatility index to control changes in the perception of risk, being considered an external interference and its respective impact on the return. In addition, IVolBR makes it possible to identify assets that are more sensitive to volatility and, subsequently, it becomes possible analyze the relation between fundamentalist signals and the return on these assets. Thus, one can make good use of this important characteristic of IVol-BR to capture a future measure of volatility, and outline a fundamental analysis strategy by taking into account the behavior of signals in the context of market volatility.

In view of the exposed problem, the following research question arises: How do fundamentalist signals relate to returns in different volatility scenarios?

Therefore, we investigate the usefulness of fundamental analysis, relating their respective signs to the return of companies, differentiated into groups, according to the criterion of sensitivity to the IVol-BR market volatility index. In addition, the use of fundamental signals to identify assets with a perspective of positive returns in future time intervals will be investigated, with the distinction of periods where there is high volatility, these being considered periods of shocks. From this point on, the relevance of accounting variables will be examined with respect to the possibility of signaling significant results of returns, even in different risk contexts.

As advocated by Abarbanell and Bushee (1998), one of the conditions for obtaining positive returns is that the information contained in the fundamental analysis anticipates the entity's financial future, which can be favored by observing the fundamentalist signs. The authors investigate the possibility of fundamentalist signals bringing an additional advantage in relation 
to the analysis of the projection of cash flows. However, in a context of extreme volatility events, such as moments of market stress or herd effects, it is possible for agents to make decisions not only on the basis of fundamentalist signals, but by acquiring safer assets. Such behavior is considered an asymmetric reaction, defended by the behavioral finance literature, as seen in Kuhnen (2015).

This asymmetric behavior is correlated with the VIX volatility index, which Whaley (2000) presents as an index of fear (investor fear gauge). Such an index is constructed from the implied volatilities of the S\&P 100 index options, and is, by definition, a measure of the expected risk. Whaley (2000) also points out that high levels of VIX coincide with periods of market turmoil, and, for the author, such turbulence may come from a threat of war, unexpected change in interest rates, or any other unexpected external event with a high probability of impact on the market. Therefore, the higher the VIX, the greater the expected volatility, reflecting a greater fear of the investor, according to the author.

The volatility proxy incorporated in this particular study is the Volatility Index of the Brazilian stock market IVol-BR, considering for periods of shock the quarters where the average of the daily IVol-BR index was high.

Panel data estimators were used, and their results indicate that the usefulness of fundamentalist analysis changes due to the volatility context, such change occurs on two fronts:

i. According to the company's sensitivity to risk measurement IVol-BR.

ii. Change referring to shock periods, that is, the level of market volatility within the quarter.

The relevance of the research comes from the possibility of showing fundamentalist signs capable of explaining the company's future return in periods of shock, given different company's sensitivity to volatility. The findings will help investors to build investment strategies based on fundamentalist signals, and to verify the adherence of this strategy in different risk scenarios.

It is known that the Brazilian stock market is small, when compared to the American one, with few companies covered by analysts. Therefore, the results related to the relevance of accounting information are especially important for investors without access to market analysts and other individuals who are eager to learn about investment strategies from fundamentalist variables.

With regard to academic contribution, as highlighted by Barak, Azadeh and Ortobelli (2017), research on equity returns and risks address one of the biggest concerns of decision makers, however, although many authors have separately investigated indicators of a different nature, one must always follow with a hybrid combination of risk variables and metrics, which the authors call Fusion Methods. This contributes to the need for research raised by Barak, Azadeh and Ortobelli (2017) when addressing fundamentalist signals in joint consideration with volatility indicators.

Therefore, the research presents an exploratory approach to the fusion method applied in Brazil by promoting the integration between accounting indicators and volatility metrics, aiming to analyze the behavior of fundamental signals in different scenarios, in addition to providing a differentiation of companies according to their sensitivity to volatility, such a differential method is a tool with real potential for practical application.

Furthermore, the work contributes by structuring and presenting a form of fundamental analysis that, according to Nti, Adekoya and Weyori (2019) by presenting a nature of unstructured data, represents a difficult challenge, so the research seeks to contribute to this challenge by presenting evidence of adherence to the technique. Nti, Adekoya and Weyori (2019) ratify that the fundamentalist analysis is proven to be a good indicator of the movement of asset prices, as seen in de Tsai and Wang (2017) and Zhang, Zhang, Wang, Yao, Fang and Philip (2018). 
BBR

17

624

\section{THEORETICAL REFERENCE}

It is known that changes in fundamentalist variables cause variations in stock prices. From this, Abarbanell and Bushee (1998) argue that it is possible to use fundamentalist analysis in conjunction with econometric tools to improve price efficiency or alternatively, exploit the wrong prices, through the analysis of the signals. Thus, one of the conditions for obtaining abnormal returns through signals is that the market temporarily underutilizes the information contained in the fundamental signals. These signals are value drivers and determinants of the entity's market value.

Fundamentalist signals can be divided into three groups: Profitability, Capital Structure and Operational Efficiency. Chart 1 shows the fundamentalist signs to be used and their respective expected relation with the return, as well as the references that support such information.

Regarding the Gross Margin (GM) signal, according to Abarbanell and Bushee (1998), an increase in the percentage variation in the gross margin, in relation to sales, indicates an improvement in performance. For Anderson, Hyun and Yu (2017) a positive value of the gross margin signal shows good news about consumer demand and, therefore, a positive relation with the company's performance. The authors explain that a higher gross margin is a desirable factor, as it represents a greater potential for obtaining more profits. In addition, there are indications that the company was able to differentiate its products from those of its competitors.

Anderson, Hyun and $\mathrm{Yu}$ (2017) point out that businesses with a higher gross margin are better prepared against unforeseen increases in production costs, competition or other adverse economic factors. A reduction in gross margin is viewed negatively, since poor sales performance with a slowing demand usually leads to lower gross margins. In addition, Anderson, Hyun and $\mathrm{Yu}$ (2017) explain that as the improvement in efficiency is obtained during the most developed stage of the organization, through the increase of knowledge of the operations, a decrease in the gross margin is seen as bad news for the entities, because these companies may have to reduce the price of their products due to falling growth rates, increased competition and reduced market share.

Abarbanell and Bushee (1997) found statistically significant evidence that variations in the gross margin have a negative impact on the entity's performance. In the Brazilian context Malta and Camargos (2016) analyzed the hypothesis that positive variations in the gross margin positively impact the return, however their results were not statistically significant for the exclusive group with preferred shares or for the group only composed of common shares, however, when the model is run with both types of shares together, there is a statistically significant and positive coefficient for the gross margin signal associated with the return, thus the need arises to better investigate how this signal behaves in the Brazilian market.

According to Copeland, Koller and Murrin (2006) it is the cash flow that is directly related to the company's value. In this research, the explanatory capacity of cash flow (CASH) to predict future returns will be analyzed, with a positive relation between cash flow and expected return, as shown in the work of Bastos et al. (2009), where operating cash flow was the most relevant measure for creating value. Regarding such accounting measures, Malacrida (2009) suggests that profit has more information capacity than cash flow to explain the companies' current returns. However, cash flow is more relevant than profit to explain future stock returns. According to Malacrida (2009), these results indicate that the future return is associated with the current cash flow of the companies, while the current return is associated with the current profit. 
Chart 1

Fundamentalist signs.

\begin{tabular}{|lll|}
\hline Group & \multicolumn{1}{c}{ Fundamental signal } & Expected signal
\end{tabular}

Source: Elaborated by the authors.

Malacrida (2009) also points out that the relevance of the cash flow accounting variable may depend on the type of share, whether preferred or common, it is possible that for shareholders with voting rights, who are more concerned with the future and the continuity of organization, the cash flow has a higher level of relevance to future returns. Thus, taking into account that the investor with common stocks has a greater interest in the control and decision-making power over the company, it can be assumed that an accounting indicator capable of representing the maintenance of the entity's continuity and its future results is his biggest object of interest.

According to Lambert (2011) it is expected that free cash flow is positively related to future profit, since more free cash should provide more flexibility to take advantage of possible investment opportunities, for example, with research and development. In the Brazilian context Perobelli, Famá, and Sacramento (2016), point out that favorable information about future profits and cash flows contributes to the valuation of shares on the date zero, thus a positive relation between cash flow and return is expected. 
BBR

17

626

Abarbanell and Bushee (1998) built the CAPEX signal related to capital expenditures, to test the hypothesis that a positive change in CAPEX represents good news for the return in a scenario in which the company's specific capital expenditures exceed average expenditures of the industry's capital, however, its results did not prove this hypothesis. Haryanto and Retnaningrum (2019), on the other hand, showed a relevant and positive relation between CAPEX and the entity's profit, and, in addition, this signal remained positive and valid in the simple regression models with revenue, return on investment and number of customers.

In the Brazilian market, Wanderley Villaschi, Caio Galdi and Neris Nossa (2011) found a valid and positive relation between CAPEX and return, in their researchusing panel data estimated by fixed effects, with the CAPEX signal coefficient being positive and statistically significant, however the authors point out that CAPEX was significant at $1 \%$ when using the 12 -month return as a dependent variable, however, when using the 24-month return, this variable lost significance at $1 \%$, but remained significant at $5 \%$. For Mohanram (2005), increases in capital expenditures can increase future sales, which provides a growth in profits and, with this, increases the likelihood that companies will meet market expectations.

Regarding changes in total debt in relation to total assets (CHGDEBT), Yan and Zheng (2017) concluded that indebtedness is a negative predictor for the future return of the stock. The authors explain that a disproportionately large amount of debt indicates a liquidity problem. Lambert (2011) argues that the higher the percentage of debt over total assets, the greater the risk of the company not meeting its obligations, and the higher the rate required for issuing new debt securities. According to the findings of Kimmel, Weygandt and Kieso (2005), indebtedness can be expected to be inversely related to the following year's profit and, consequently, has a negative impact on return.

In addition, Yan and Zheng (2017) state that companies face a risk of rolling over short-term debt, especially during periods of financial crisis. If shareholders underestimate this rollover risk and the cost of financial difficulties, the market will temporarily overvalue entities with high indebtedness. For Yan and Zheng (2017) when more public information about indebtedness is released to the market in subsequent periods, companies experience low future returns and perhaps even negative ones.

For Abarbanell and Bushee (1998) the effective rate tax variable (ETR), is intended to capture changes in the rate not attributable to permanent factors, such as changes in rates related to legal taxes. Thus, a reduction in the effective rate indicates that gains will not persist at current levels and this is a bad sign for the entity's return. Likewise, Wahab and Holland (2012) found a negative relation between the ETR variable and the market value of British companies. Such a negative sign is also a finding by Desai and Dharmapala (2009) where ETR is observed, and used as a proxy for tax aggressiveness, negatively impacting the stock price. In the Brazilian context, Soares and Galdi (2011) analyzed the relation of the effective rate and its impact on returns, however, their results were not significant, evidencing the need for future investigations regarding the relation between the ETR and returns.

By the value of inventories, for Abarbanell and Bushee (1998), when the stock of finished products increases faster than sales, it is interpreted as bad news for profits and, therefore, there is a negative impact on returns. This scenario signals a reduction in demand, with a risk of reduced revenue. There is also an indication of higher costs for maintaining inventory, costs related to renting space, for example, in addition to the opportunity costs of capital employed and stationed there. For Matarazzo (2010), inventories are the items with the highest risk of current assets, as 
they are subjected to obsolescence, deterioration, theft and, finally, are not being sold, therefore, they will not be converted into cash, which is a risk that depends on the company, the market and the economic situation. As with inventories, the other considerable items of current assets present intrinsic risks, such as accounts receivable, where there is a risk that the debtor will not pay, so it depends on the ability to pay of third parties.

However, for Ball, Gerakos, Linnainmaa and Nikolaev (2016) the signaling of inventories (INV) has ambiguities, as observed in entities that are growing, where there is a need for net investment in working capital due to growth. Ball et al. (2016) state that growth typically changes the level of working capital, such as inventories and accounts receivable, thus impacting on current cash. Thomas and Zhang (2002) showed that entities with increased inventories had higher levels of profitability, growth, and abnormal returns and that these trends are reversed immediately after changes in the direction of stocks.

The Receivables sign (ARab) represents the change in accounts receivable in relation to the change in sales revenue. A decrease in this signal would signal difficulties in collection and higher expenses with doubtful debtors in the future or, alternatively, notice of a future slowdown in sales. Abarbanell and Bushee (1998) defend in their findings a negative sign for receivables, suggesting that an expansion of accounts receivable in relation to sales, is generally a bad indicator of sales.

In the national context, Oliveira, Silva, Hernandes and Ribeiro (2019) investigated the impact of receivables on future returns, based on the article by Deloof (2003), in which a negative relation between receivables and returns was verified. The authors hypothesized that an increase in the amounts of receivables negatively impacted returns but found no significant relation between the variable receivable and returns, which leaves a gap to be investigated in the Brazilian context.

For Abarbanell and Bushee (1998) increases in sales and administrative expenses (SeA) in relation to the percentage of variation in sales, signals an increase in the company's expense structure, leading to a reduction in future profits, which translates into a negative impact for return, however, Anderson, Banker, Huang and Janakiraman (2007) evidenced that abnormal positive returns can be obtained in formed portfolios investing in companies with high increases in sales and administrative expenses (SeA), in this scenario, an increase in the signal can convey positive information about the company's expectations regarding future earnings.

Relating fundamentalist signals to risk metrics, in the Brazilian context, Figliori, Lima, Pimenta and Pereira (2015) are mentioned, who analyzed the association between the signals: company size, liquidity, financial leverage, cash generation, profitability and risk indicators of the actions included in the corporate sustainability index (ISE). For the authors, volatility, in the risk model, aims to capture the variations in stock returns in the period that corresponds to the window of the considered event: the disclosure of the composition of the ISE. The Volatility of Shares and Abnormal Returns to Value at Risk (VaR) were included in the risk model. The authors emphasize the greater explanatory capacity of risk variables compared to fundamentalist variables.

It is observed that fundamentalist signals can be affected by external shocks, such as reduction shocks in demand due to an economic recession, political risks, among others. In other words, the fundamentalist signs of the entity may adjust due to shock, since companies adjust to factors that influence their demand, for example, these adjustments refer to the decision to expand or contract production, to postpone the beginning of a project, deciding on a temporary or even permanent abandonment. 
BBR

17

628

Volatility is considered a proxy for external shocks, since it is a dispersion metric that represents the perception of existing market risk. For this reason, changes in risk factors cause changes in the volatility index, such variations tend to be reflected in the return without a direct association with fundamentalist signals. On such an association between volatility and return, Boyer, Mitton and Vorkink (2009) found a negative relation between idiosyncratic volatility and return, in their models it was also shown that the average returns are negatively related to the expected idiosyncratic asymmetry.

\section{METHODOLOGY}

The study is delimited by non-financial companies with shares traded on B3 - Brasil, Bolsa, Balcão - during the third quarter of 2011 until the second quarter of 2018. The reason for choosing this period is the fact that it was from this time on that IVol-BR started to be calculated and disclosed. Also, with the use of IVol-BR, made available by the NEFIN / USP database Research Center for Financial Economics at the University of São Paulo, the sensitivity dummy variable for each company was obtained individually. The other data were collected in the Capital IQ database of Standard \& Poor's. After the collection, the first cut eliminated companies that went in or out of market within this window. This criterion was established to prevent companies with little information from being present in the sample and causing a relevant change in the composition of the portfolio of companies analyzed each year. This first filter resulted in a total of 266 companies present in the data base.

Next, a liquidity cut was made based on the presence on the stock exchange. Only companies whose shares were traded in at least $80 \%$ of the sessions over the period were kept in the sample. Since the proposed analysis depends on the relation between the prices of the assets being traded on the stock exchange and the accounting indicators, it is not reasonable to consider shares that do not have liquidity, since the sample needs to be composed of companies that in fact reflect the relevant information available in the market in their prices. In addition, part of the methodology used was based on the estimation of a regression for each company based on the daily returns and the variation of the IVol-BR, the lack of liquidity would directly impact this stage of the work and therefore only the companies with greater liquidity would generate reliable information. This criterion resulted in a final sample of 160 companies that were observed over the 28 quarters.

The fundamentalist signs were standardized following the criterion of subtracting their average value, divided by the standard deviation $(\mathrm{Z}=(\mathrm{X}-\bar{x}) / \sigma)$. For Gujarati (2009), this procedure allows the comparison of the impact of different variables measured at different scales, since all of them will be standardized in their $\mathrm{Z}$ value, and, with this, one can use the coefficients of the model obtained as a measure of the relative strength of the various regressors under analysis.

After calculation and standardization of the fundamentalist signals, the stage of elaboration of volatility scenarios was made. In contrast to previous studies, this research will consider the volatility index of the Brazilian stock market IVol-BR as a volatility proxy. For this purpose, the quarters where the average daily IVol-BR index was high were analyzed. The average of the index for each month was ordered and the quarters that have the average among the $25 \%$ highest values, upper quartile, were classified as negative shock quarters, thus assuming a value of 1 in the negative shock dummy. 
Even though these shocks occur in the market, it was not expected that all companies would be affected in the same way, so a model was created to assess whether a company is seriously sensitive to this shock or not. This sensitivity classification was elaborated as follows: a regression is calculated for each of the companies, 160 regressions in total, where the daily return of the company was explained by the daily variation of IVol-BR, if the regression coefficient was significant at $10 \%$, the company would be considered sensitive to shock and assumed a value of 1 on the dummy, otherwise the company would be non-sensitive, assuming a value of 0 on the dummy. At this point, the independent variables in the study were calculated: the dummy of negative shock and sensitivity, together with the fundamentalist signals.

The dependent variable is the company's quarterly return, calculated as the difference between the natural $\log$ price on the last trading day within the quarter and the natural log price on the first trading day of the quarter. For the share price, the closing price with adjustments was considered.

After calculating all the variables of the study, we have the following general data model:

$$
\operatorname{Ret}_{i t}=\beta_{0, i t}+\sum_{k=1}^{8} \beta_{k, i t} x_{k, i t}+D y_{\text {sens. }}+\operatorname{Dshock}_{(-)}+\sum_{k=1}^{n}\left(\beta_{k, i t} x_{k, i t} * \operatorname{Dshock}_{(-)}\right)
$$

Where:

Ret $_{i t}$ is the dependent variable represented by the stock return $\mathrm{i}$ at time $\mathrm{t}$.

$\beta_{0, i t}$ is the differentiated intercept for each cross-section unit $\mathrm{i}$ at time $\mathrm{t}$.

$\beta_{k, i t}$ Angular coefficient for each cross-sectional unit i at time t.

$x_{k, i t}$ They are the regressors, that is, the independent variables represented by the 8 fundamentalist signs $\mathrm{k}$ of each asset $\mathrm{i}$ at time t, as shown in the Chart 1: Fundamentalist Signs.

$D y_{\text {sens }}$ It is the asset sensitivity dummy to the IVol-BR index, it assumes a value of 1 if the asset is sensitive and zero otherwise.

Dshock $_{(-)}$It is the dummy representative of the negative shock calculated from the upper quartile of the IVol-BR volatility index.

$\beta_{k, i t} * x_{k, i t} * D s h o c k_{(-)}$it is the interaction between the fundamentalist signals and the shock dummy.

The regressors represented by the 8 fundamentalist signals with their respective expected signals listed in Chart 1, refer to: ARab (Accounts Receivable): Difference between the variation in receivables (RECT) and the variation in sales (SALES), CAPEX: Difference between the CAPEX variation of the sector and the CAPEX variation of the company, CASH: Ratio between cash flow and total assets, CHGDEBT: Changes in the ratio of total liabilities to total assets, ETR (Effective tax rate): effective tax rate of company, GM (Gross Margin): standardized difference between the variation of the gross margin and the variation of sales, INV (Inventory): Difference between the variation of the total monetary amount in inventories (INVTQ) and the amount of sales (SALES), SeA (sales and administrative): difference between the variation in sales and the variation in administrative and sales expenses.

The interaction variables are used in order to verify the impact of shocks on the relation between fundamentalist signals and returns. That is, based on the statistical significance and algebraic signs, it will be verified how the signs are impacted by periods of shocks. 
BBR

17

630

Using the R software, estimators for panel data were obtained, the Chow, Hausman and Lm tests of Breusch Pagan were used, the Chow test showed p value $=2.2 \mathrm{e}-16$, whereas Lm of BreuschPagan has $\mathrm{p}$ value $=2.2 \mathrm{e}-16$, and Hausman pvalor $=0.084$, thus, the panel data estimated by random effect $(\mathrm{RE})$ is the most suitable. To validate the assumptions of the models were made Breusch-Pagan tests for heteroscedasticity, Pesaran CD test of Cross-sectional dependence, analysis of the Variance Inflation Factor (VIF) for multicollinearity, and the Breusch-Godfrey test for serial autocorrelation of the residuals. Once the estimation method was chosen, attention was paid to the presence of heteroscedasticity and, in the identified cases, robust standard errors was corrected according to White's method.

In order to investigate the predictive capacity of fundamentalist signals in different time horizons, the model exposed in equation (1) was estimated using lags of independent variables. The lags consider the quarterly periodicity of the dependent variable Return at time $t$ with successive analyzes using the lagged independent variables in $\mathrm{t}-1, \mathrm{t}-2$ quarters. The accounting data that make up the signs were lagged as follows: the database of returns starts in 2011.3 and that of fundamentalist signs starts from the statements referring to the 2011.2 quarter, which is released in 2011.3, thus, we have the first analysis with the temporally paired data called t. After this first analysis, the lags in $\mathrm{t}-1$ and $\mathrm{t}-2$ were also evaluated in order to verify the explanatory capacity of the signals to predict returns over time.

As a test of the model's robustness, after estimating the main model presented in equation (1), the model was re-estimated by dividing the companies into 2 groups, one with the companies that were sensitive to volatility and the other with non-sensitive companies, according to the one identified by the sensitivity dummy.

\section{RESULT ANALYSIS}

\subsection{Presentation and analysis of the Results for group 01 With all companies}

Table 1 shows, in the first three columns, the results of the estimated model without the interactions between fundamentalist signals and the negative shock dummy, and in the following three columns the estimates with the aformentioned interactions. Regarding the sensitivity dummy variable, $73 \%$ of the companies observed are sensitive to IVol-BR, that is, 116 companies. Each model is also estimated at the lags specified in the methodology, aiming to verify how the explanatory capacity of such signals on the return behaves over time. The negative shock quarters identified refer to: 2011.3, 2011.4, 2014.4, 2015.3, 2015.4, 2016.1, 2016.2, 2018.3.

It is observed that some quarters relate to internal factors such as elections and the impeachment of the President of the republic, this process started on December 2, 2015 and was completed on August 31, 2016, creating economic, political and juridical instability in Brazil, such instability is seen as an increase in uncertainty on the part of investors and, as a result, it appears that the IVol-BR index presents extreme values in the reported period.

The Chow test has p-value $=2.2 \mathrm{e}-16$. The Breusch-Pagan Lm test, on the other hand, presented $\mathrm{p}$ value $=2.2 \mathrm{e}-16$, and the Hausman test, $\mathrm{p}$ value $=0.084$, thus, the random effects estimator is the most appropriate. The Breusch-Godfrey test for serial autocorrelation of the residuals obtained p-value $=0.24$. The residuals independence test between entities (Pesaran CD test) was carried out, where a value greater than 0.05 was obtained for all models, therefore, there is no cross-sectional dependency. By the asymptotic central limit theorem, the assumption of normality of the residues can be relaxed. Statistical significance: $1 \%\left({ }^{* *}\right), 5 \%\left({ }^{* *}\right)$, and $10 \%\left(^{*}\right)$. 
Table 1

Results of the models estimated by random effects with all companies

\begin{tabular}{|c|c|c|c|c|c|c|}
\hline $\begin{array}{l}\text { Dependent } \\
\text { Variable: Return }\end{array}$ & $(\mathrm{t})$ & $(\mathrm{t}-1)$ & $(\mathrm{t}-2)$ & $(\mathrm{t})$ & $(\mathrm{t}-1)$ & $(\mathrm{t}-2)$ \\
\hline Dshockneg & $\begin{array}{l}-0.030^{*} \\
(0.017)\end{array}$ & $\begin{array}{l}-0.031^{*} \\
(0.017)\end{array}$ & $\begin{array}{l}-0.042^{* *} \\
(0.019)\end{array}$ & $\begin{array}{l}-0.028 \\
(0.025)\end{array}$ & $\begin{array}{l}-0.076^{* * *} \\
(0.026)\end{array}$ & $\begin{array}{l}-0.058^{* *} \\
(0.028)\end{array}$ \\
\hline Arab*Dshockneg & & & & $\begin{array}{c}1.813 \\
(1.125)\end{array}$ & $\begin{array}{l}-1.251 \\
(1.586)\end{array}$ & $\begin{array}{l}1.138^{* * *} \\
(0.412)\end{array}$ \\
\hline CAPEX*Dshockneg & & & & $\begin{array}{l}-0.008 \\
(0.008)\end{array}$ & $\begin{array}{l}-0.009 \\
(0.009)\end{array}$ & $\begin{array}{l}-0.010 \\
(0.008)\end{array}$ \\
\hline $\mathrm{CASH}^{*}$ Dshockneg & & & & $\begin{array}{l}-0.002 \\
(0.008)\end{array}$ & $\begin{array}{c}0.008 \\
(0.008)\end{array}$ & $\begin{array}{c}0.038 \\
(0.030)\end{array}$ \\
\hline $\begin{array}{l}\mathrm{CHG}_{-} \\
\text {DEBT*Dshockneg }^{*} \text { Ds }\end{array}$ & & & & $\begin{array}{c}0.012 \\
(0.008)\end{array}$ & $\begin{array}{c}0.007 \\
(0.008)\end{array}$ & $\begin{array}{c}0.002 \\
(0.009)\end{array}$ \\
\hline ETR*Dshockneg & & & & $\begin{array}{l}-0.001 \\
(0.007)\end{array}$ & $\begin{array}{c}0.016 \\
(0.015)\end{array}$ & $\begin{array}{l}-0.009 \\
(0.014)\end{array}$ \\
\hline GM*Dshockneg & & & & $\begin{array}{l}-1.689 \\
(1.066)\end{array}$ & $\begin{array}{l}-1.970 \\
(1.532)\end{array}$ & $\begin{array}{l}-2.375^{*} \\
(1.380)\end{array}$ \\
\hline INV*Dshockneg & & & & $\begin{array}{l}-0.106 \\
(0.076)\end{array}$ & $\begin{array}{c}0.034 \\
(0.103)\end{array}$ & $\begin{array}{l}-0.233 \\
(0.231)\end{array}$ \\
\hline SeA*Dshockneg & & & & $\begin{array}{l}-0.006 \\
(0.013)\end{array}$ & $\begin{array}{c}0.012 \\
(0.014)\end{array}$ & $\begin{array}{c}0.090 \\
(0.106)\end{array}$ \\
\hline Dummysensi & $\begin{array}{l}0.024^{* * *} \\
(0.008)\end{array}$ & $\begin{array}{l}0.023^{* * *} \\
(0.008)\end{array}$ & $\begin{array}{l}0.024^{* * *} \\
(0.008)\end{array}$ & $\begin{array}{l}0.024^{* * *} \\
(0.008)\end{array}$ & $\begin{array}{l}0.022^{* * *} \\
(0.008)\end{array}$ & $\begin{array}{l}0.023^{* * *} \\
(0.008)\end{array}$ \\
\hline ARab & $\begin{array}{l}-0.0001 \\
(0.003)\end{array}$ & $\begin{array}{r}-0.0003 \\
(0.003)\end{array}$ & $\begin{array}{c}0.003 \\
(0.003)\end{array}$ & $\begin{array}{r}-0.0001 \\
(0.003)\end{array}$ & $\begin{array}{c}-0.0004 \\
(0.003)\end{array}$ & $\begin{array}{c}-1.134^{* * *} \\
(0.412)\end{array}$ \\
\hline CAPEX & $\begin{array}{c}0.002 \\
(0.003)\end{array}$ & $\begin{array}{c}0.002 \\
(0.003)\end{array}$ & $\begin{array}{c}0.004 \\
(0.003)\end{array}$ & $\begin{array}{c}0.004 \\
(0.004)\end{array}$ & $\begin{array}{c}0.003 \\
(0.004)\end{array}$ & $\begin{array}{c}0.006 \\
(0.004)\end{array}$ \\
\hline $\mathrm{CASH}$ & $\begin{array}{l}0.008^{* *} \\
(0.003)\end{array}$ & $\begin{array}{l}0.011^{* * *} \\
(0.003)\end{array}$ & $\begin{array}{l}-0.019^{* * *} \\
(0.003)\end{array}$ & $\begin{array}{c}0.010 \\
(0.007)\end{array}$ & $\begin{array}{c}0.004 \\
(0.007)\end{array}$ & $\begin{array}{c}-0.020^{* * *} \\
(0.003)\end{array}$ \\
\hline CHG_DEBT & $\begin{array}{l}-0.008^{* *} \\
(0.003)\end{array}$ & $\begin{array}{l}-0.001 \\
(0.003)\end{array}$ & $\begin{array}{l}-0.003 \\
(0.004)\end{array}$ & $\begin{array}{l}-0.01^{* * *} \\
(0.004)\end{array}$ & $\begin{array}{l}-0.002 \\
(0.004)\end{array}$ & $\begin{array}{l}-0.002 \\
(0.004)\end{array}$ \\
\hline ETR & $\begin{array}{l}-0.001 \\
(0.003)\end{array}$ & $\begin{array}{l}-0.003 \\
(0.003)\end{array}$ & $\begin{array}{c}0.003 \\
(0.003)\end{array}$ & $\begin{array}{l}-0.001 \\
(0.004)\end{array}$ & $\begin{array}{l}-0.004 \\
(0.004)\end{array}$ & $\begin{array}{c}0.003 \\
(0.004)\end{array}$ \\
\hline GM & $\begin{array}{l}-0.0001 \\
(0.003)\end{array}$ & $\begin{array}{l}-0.002 \\
(0.003)\end{array}$ & $\begin{array}{l}-0.007^{*} \\
(0.003)\end{array}$ & $\begin{array}{c}-0.00004 \\
(0.003)\end{array}$ & $\begin{array}{l}-0.002 \\
(0.003)\end{array}$ & $\begin{array}{l}-0.006^{*} \\
(0.003)\end{array}$ \\
\hline INV & $\begin{array}{l}0.014^{* * *} \\
(0.004)\end{array}$ & $\begin{array}{l}-0.004 \\
(0.004)\end{array}$ & $\begin{array}{l}-0.001 \\
(0.004)\end{array}$ & $\begin{array}{c}0.013 \\
(0.030)\end{array}$ & $\begin{array}{c}0.039 \\
(0.030)\end{array}$ & $\begin{array}{l}0.070^{* * *} \\
(0.026)\end{array}$ \\
\hline SeA & $\begin{array}{l}-0.003 \\
(0.004)\end{array}$ & $\begin{array}{l}0.0002 \\
(0.004)\end{array}$ & $\begin{array}{l}-0.002 \\
(0.004)\end{array}$ & $\begin{array}{l}-0.003 \\
(0.005)\end{array}$ & $\begin{array}{l}-0.001 \\
(0.005)\end{array}$ & $\begin{array}{l}-0.002 \\
(0.004)\end{array}$ \\
\hline Intercepto & $\begin{array}{l}-0.027^{* *} \\
(0.011)\end{array}$ & $\begin{array}{l}-0.023^{* *} \\
(0.011)\end{array}$ & $\begin{array}{l}-0.025^{* *} \\
(0.011)\end{array}$ & $\begin{array}{l}-0.027^{* *} \\
(0.011)\end{array}$ & $\begin{array}{l}-0.023^{* *} \\
(0.011)\end{array}$ & $\begin{array}{c}-0.041^{* * *} \\
(0.012)\end{array}$ \\
\hline
\end{tabular}


BBR

17

632

Table 1

Cont.

$$
\operatorname{Ret}_{i t}=\beta_{0, i t}+\sum_{k=1}^{8} \beta_{k, i t} x_{k, i t}+D y_{\text {sens. }}+D \operatorname{shock}_{(-)}+\sum_{k=1}^{n}\left(\beta_{k, i t} x_{k, i t} * D \operatorname{shock}_{(-)}\right)
$$

\begin{tabular}{lcccccc}
\hline $\begin{array}{l}\text { Dependent } \\
\text { Variable: Return }\end{array}$ & $(\mathrm{t})$ & $(\mathrm{t}-1)$ & $(\mathrm{t}-2)$ & $(\mathrm{t})$ & $(\mathrm{t}-1)$ & $(\mathrm{t}-2)$ \\
\hline Observations & 4,480 & 4,320 & 4,160 & 4,480 & 4,320 & 4,160 \\
$\mathrm{R}^{2}$ Adjusted & 0.007 & 0.003 & 0.010 & 0.006 & 0.004 & 0.011 \\
F Statistics & $4.027^{* * *}$ & $2.543^{* * *}$ & $5.269^{* * *}$ & $2.643^{* * *}$ & $2.108^{* * *}$ & $3.754^{* * *}$ \\
\hline
\end{tabular}

Source: Elaborated by the Authors.

Note: ARab (Accounts Receivable): Difference between variation in receivables (RECT) and variation in sales (SALES) CAPEX: Difference between the sector's CAPEX variation and the company's CAPEX variation.

$C A S H$ : Relation between cash flow and total assets.

CHGDEBT: Changes in the ratio of total liabilities to total assets.

ETR (Efective tax rate): Effective tax rate of the company.

GM (Gross Margin): Standardized difference between gross margin variation and sales variation.

INV (Inventory): Difference between the change in the total monetary amount in inventories (INVTQ) and the amount of sales (SALES).

SeA (sales and administrative): Difference between the variation in sales and the variation in administrative and sales expenses.

Descriptive statistics, multicollinearity testing and correlation analysis are not presented due to space restrictions but can be made available by the authors on demand.

The results highlight the possibility of modeling the return of shares using fundamentalist signals, since the explanatory power of the model is statistically valid. The dummies of negative shock and sensitivity showed the expected signs and were consistent with the presented theory, both when compared to national works like Figliori et al. (2015) and researches related to the American market, as observed in Abarbanell and Bushee (1998), Lambert (2011) and Wahab, Teitel and Morzuch (2017).

The shock dummy, representative of the upper quartile, where there is high volatility, has a significant and negative relation with returns. Regarding to the sensitivity dummy, there is a significant positive relation with returns and it was consistent throughout all estimates. It is known that investors demand an additional return in scenarios of greater volatility, therefore, for assets sensitive to the risk proxy, the expected return tends to be greater.

Regarding the Receivables signal, there is a significant and negative coefficient in the lag at $\mathrm{t}-2$, however when there is interaction with the shock dummy the observed value is positive and significant, indicating that in high volatility contexts this variable would not impact the stock return, since the coefficients (with and without interaction) have close values. The result found without the interaction for this signal complements the research by Oliveira et al. (2019) where the hypothesis was presented that an increase in the receivable impacts negatively the return. Since such receivables are certainly not guaranteed to be paid by the debtor, their relation with the return is expected to be negative. In addition, an increase in receivables indicates an increase in sales with installments, which may signal a certain difficulty in negotiating with customers to receive them in shorter periods, which could lead to financial difficulties. 
The CAPEX represents capital expenditures and did not present a statistically significant relation with returns, not even in the interaction with the negative shock dummy. These findings are in line with those of Abarbanell and Bushee (1998), so it is necessary to analyze this variable later with the distinction of companies according to their sensitivity.

It is worth mentioning that the CASH indicator has the most consistent result, being significant in more specifications of the different models when compared to the other signals. This indicator was obtained by the ratio between cash flow and total assets, in order to mitigate the size effect, according to Lambert (2011) and Wahab, Teitel and Morzuch (2017). The results show a positive relation with the returns at $\mathrm{t}$ and $\mathrm{t}-1$. This result is in line with Perobelli, Famá and Sacramento (2016), where favorable information on future profits and cash flows contributes to the valuation of shares on the zero date. Note, however, that at $\mathrm{t}-2$ this indicator maintains its predictive capacity, but with a negative sign. This result may indicate that persistent cash can be seen as negative news, since investors expect companies to provide an effective destination for excess cash, that is, they invest in projects with a rate of return within the expectations of the market or distribute the cash as profit to shareholders. It should also be noted that the CASH signal is not affected by negative shocks.

Changes in indebtedness CHGDEBT, on the other hand, showed a significant and negative relation with the returns in $\mathrm{t}$, a result that remained in the version with the variables of interaction with the negative shock dummy. Thus, it appears that positive changes in the level of indebtedness negatively impacts the return, confirming the research hypothesis presented by Yan and Zheng (2017) and Lambert (2011).

Regarding the sign referring to the effective tax rate ETR, there is no evidence that it has explanatory capacity on return, so it is not possible to observe the expected relation according to Desai and Dharmapala (2009) and Wahab and Holland (2012). However, this result is in line with Abarbanell and Bushee (1998).

The GM variable representing the gross margin is significant only at $\mathrm{t}-2$, with a negative sign, this is in line with Abarbanell and Bushee (1997), where a negative coefficient for the gross margin signal related to future performance from the entity was obtained. It is noteworthy that in the interaction with the shock dummy, this indicator maintains its significance and negative sign in the same lag in $\mathrm{t}-2$, with this there is evidence that even in high volatility scenarios such an accounting signal is relevant.

The fundamentalist variable INV, representative of inventories, presents itself as the last sign of the model with significant and positive impact with the returns in $\mathrm{t}$ and $\mathrm{t}-2$ in the version with interaction variables. This algebraic sign agrees with the findings of Abarbanell and Bushee (1998), which suggest that increases in inventories have a negative relation with profits and, therefore, would negatively impact returns. The positive relation found in this study can be justified by the fact that with larger inventories, entities are more able to adopt aggressive market strategies to face competitors, and such strategies generate prospects for positive returns. This conjecture is in line with Ball et al. (2016) where the authors indicate that inventories have ambiguities since, for example, they can characterize growth and the need for net investment in working capital.

Finally, for the 1st group with all companies, the fundamentalist signs related to administrative and sales expenses are not significant. 
17

\subsection{Presentation and analysis of ReSUlts For COMPANIES SENSITIVE AND NON-SENSITIVE}

TO SHOCKS

In this second stage of the analysis, as a robustness test, companies sensitive to IVol-BR and non-sensitive companies are observed separately. The models were estimated by random effects as justified by the tests. Within each group, sub-analyzes were carried out with the fundamentalist signals outdated at $\mathrm{t}-1$ and $\mathrm{t}-2$ in order to verify how the explanatory capacity of such signals behaves time over time, models with and without the interaction of the signals with the shock dummy where presented, as can be seen in Table 2 on the next page.

As expected, for companies without sensitivity to IVol-BR, there was no statistically significant relation between the negative shock dummy and the returns. However, for the group of companies sensitive to IVol-BR, there is a significant and negative relation in the lag in $\mathrm{t}-1$, both in the model with the interaction variables and in the model without them. These results confirm the findings of Boyer, Mitton, and Vorkink (2010).

For the Receivables signal (Arab) there is evidence of a negative and small significant relation in the t-lag, in both models, for companies sensitive to IVol-BR. This result is in line with the findings of Abarbanell and Bushee (1998), who identified significant and negative coefficients between receivables and return. The absence of statistical significance for the variable that interacted with the external shock dummy shows that the relation is not affected in scenarios of high volatility for the group of sensitive companies. For those not sensitive to IVol-BR, the Receivables signal is not significant, except for the interaction with the shock dummy in the lag at $\mathrm{t}-1$, where the signal is positively significant. The lack of significance is in line with the findings by Oliveira et al. (2019).

However, there is a relevant and unexpected finding when this variable is analyzed in the context of shock. In this scenario, it is noticed that the signal becomes negative for the group of sensitive companies in the interaction with the shock dummy in relation to the returns in $\mathrm{t}-1$ and $\mathrm{t}-2$, suggesting that in moments of high volatility the impact of CAPEX in the future return is negative, that is, in this context it is undesirable for the company to have a high capital expenditure, the justification for such a finding can be constructed from the assumption that such a shock signals moments of crisis and with this there is an expectation of reductions in demand which does not justify increases in CAPEX.

In the group of sensitive companies, the CASH sign showed a positive and significant relation with the return in $t$. The interaction variables show that, in times of high volatility, the impact is greater in relation to returns on $\mathrm{t}$ and $\mathrm{t}-2$. For the group with companies without sensitivity to IVol-BR, this sign is significant and positive in the lag in $\mathrm{t}-1$, and such results are in line with those advocated by Perobelli, Famá, and Sacramento (2016). However, in the lag at $\mathrm{t}-2$ this sign remains significant but with a negative signal, even in the version with an interacting model. Such a result may signal that persistent cash can be seen as negative news for future returns. Therefore, the CASH signal has an effect influenced by sensitivity to IVol-BR and by different lags.

The CHGDEBT signal remained significant and negative only in the group of companies sensitive to IVol-BR in relation to returns in $t$ and $t-1$, but not with the lag $t-2$. The lack of significance in the version that interacted with the shock dummy suggests that the effect is not changed in times of high volatility, for this group of companies. The negative significance of indebtedness is in line with the result of the negative predictor observed in Yan and Zheng (2017) and Lambert (2011). 
Table 2

Robustness test - Estimated by random effects

\begin{tabular}{|c|c|c|c|c|c|c|c|}
\hline \multirow[t]{2}{*}{ Return } & & $(\mathrm{t})$ & $(\mathrm{t}-1)$ & $(\mathrm{t}-2)$ & $(\mathrm{t})$ & $(\mathrm{t}-1)$ & $(\mathrm{t}-2)$ \\
\hline & & \multicolumn{3}{|c|}{ Without interaction } & \multicolumn{3}{|c|}{ With interaction } \\
\hline \multirow{2}{*}{ Dshockneg } & Sensitive & & $-*$ & & & $--^{* * *}$ & \\
\hline & Not sensit & & & & & & \\
\hline \multirow{2}{*}{ Arab:Dshockneg } & Sensitive & & & & & & \\
\hline & Not sensit & & & & & $+^{* *}$ & \\
\hline \multirow{2}{*}{ CAPEX:Dshockneg } & Sensitive & & & & & $-{ }^{*}$ & $-{ }^{*}$ \\
\hline & Not sensit & & & & $+^{*}$ & & \\
\hline \multirow{2}{*}{ CASH:Dshockneg } & Sensitive & & & & $++^{* * *}$ & & $+* * *$ \\
\hline & Not sensit & & & & & & \\
\hline \multirow{2}{*}{$\begin{array}{l}\mathrm{CHG}_{-} \\
\text {DEBT:Dshockneg }\end{array}$} & Sensitive & & & & & & \\
\hline & Not sensit. & & & & & & \\
\hline \multirow{2}{*}{ ETR:Dshockneg } & Sensitive & & & & & & \\
\hline & Not sensit. & & & & & & \\
\hline \multirow{2}{*}{ GM:Dshockneg } & Sensitive & & & & & & \\
\hline & Not sensit & & & & & & \\
\hline \multirow{2}{*}{ INV:Dshockneg } & Sensitive & & & & & & $-{ }^{*}$ \\
\hline & Not sensit & & & & & & \\
\hline \multirow{2}{*}{ SeAab:Dshockneg } & Sensitive & & & & & & \\
\hline & Not sensit. & & & & & & \\
\hline \multirow{2}{*}{ Arab } & Sensitive & $-{ }^{*}$ & & & $-{ }^{*}$ & & \\
\hline & Not sensit. & & & & & & \\
\hline \multirow{2}{*}{ CAPEX } & Sensíveis & & & & & & $+^{*}$ \\
\hline & Not sensit. & & & & & & \\
\hline \multirow{2}{*}{$\mathrm{CASH}$} & Sensitive & $+{ }^{* *}$ & & & & & \\
\hline & Not sensit & & $+^{* * *}$ & $-* * *$ & & & -*** \\
\hline \multirow{2}{*}{ CHG_DEBT } & Sensitive & $--^{* * *}$ & $-^{* * *}$ & & $--^{* * *}$ & $-^{* *}$ & \\
\hline & Not sensit & & & & & & \\
\hline \multirow{2}{*}{ ETR } & Sensitive & & & & & $-^{*}$ & \\
\hline & Not sensit. & & & & & & \\
\hline \multirow{2}{*}{ GM } & Sensitive & & & $-^{*}$ & & & $-^{*}$ \\
\hline & Not sensit. & $-* * *$ & $-* * *$ & $-* * *$ & $-* * *$ & $-* * *$ & -*** \\
\hline \multirow{2}{*}{ INV } & Sensitive & & & & & & \\
\hline & Not sensit & & & & & $+^{*}$ & \\
\hline \multirow{2}{*}{ SeA } & Sensitive & & & & & & \\
\hline & Not sensit. & & & & & & \\
\hline
\end{tabular}

Source: Prepared by the Authors.

Note: ARab (Accounts Receivable): Difference between variation in receivables (RECT) and variation in sales (SALES) CAPEX: Difference between the sector's CAPEX variation and the company's CAPEX variation.

$C A S H$ : Ratio between cash and total assets.

CHGDEBT: Changes in the ratio of total liabilities to total assets.

ETR (Efective tax rate): Effective rate of the company.

GM (Gross Margin): Standardized difference between the variation in gross margin and the variation in sales.

INV (Inventory): Difference between the change in the total monetary amount in inventories (INVTQ) and the amount of sales (SALES).

SeA (sales and administrative): Difference between the variation in sales and the variation in administrative and sales expenses. 
BBR

17

636

Regarding the sign referring to the effective tax rate ETR, it was found negative and significant only in relation to returns in $\mathrm{t}-1$ and only in the group of companies sensitive to IVol-BR. This finding is in line with those of Desai and Dharmapala (2009) and Wahab and Holland (2012). Abarbanell and Bushee (1998) also found a relevant and negative sign between ETR and the return. One possible explanation for this behavior may be a higher level of corporate indebtedness, resulting in a greater tax benefit for the debt, which would reduce the effective tax rate. This signal would therefore be related to a higher level of indebtedness which, as seen in the previous signal, would negatively impact future returns.

The GM signal has more significant results in the group of companies not sensitive to IVol-BR. For this group, the relation is negative in all observed lags. This fact is in line with the findings of Abarbanell and Bushee (1997), where a negative coefficient was obtained for the gross margin signal related to the entity's future performance. For the group of sensitive companies, the ratio is negative but significant at $10 \%$ only, in relation to the returns in $\mathrm{t}-2$. The results of this research differ from what was evidenced by Malta and Camargos (2016) in the Brazilian context, as their results were not significant. It is noteworthy that the signal that interacted with the negative shock dummy did not present a significant relation in any of the two groups of companies and in any lag, which shows that the relevance of the signal is not altered in times of high volatility.

For inventories (INV) the results are not very significant. Only in the versions of the models with interaction variables, a $10 \%$ positive relation was observed with returns at $\mathrm{t}-1$ in the group of sensitive companies, and a reduction in the impact of the signal on returns at $\mathrm{t}-2$ in the group of sensitive companies. Abarbanell and Bushee (1998) suggest that an increase in the inventories of finished products is seen as bad news for profits and, therefore, has a negative impact on returns.

An absence of explanatory relevance in the signs related to administrative and sales expenses can be observed.

\section{CONCLUSION}

When starting the final considerations, it becomes necessary to rescue the problem outlined: How do fundamentalist signals relate to returns in different volatility scenarios?

It is observed that the behavior of some fundamentalist signal's change according to market volatility. The results may represent empirical evidence that in these moments the investor starts to make his decisions towards an aversion of risk and not only based on the fundamentalist signals of the entity.

In this way, the research fulfills the proposed objective of ascertaining how fundamentalist signals relate to returns in different volatility scenarios. In addition, it was possible to analyze the behavior of such signs given that the company's characteristic of being sensitive or not to IVol-BR, making it evident that the explanatory capacity of fundamentalist signs is altered. The most significant results were observed for the signs related to cash, debt and gross margin.

The CASH signal has a positive relation with return, as expected. However, when observing the effect of volatility on this signal, the results show that the relation remains positive and significant only for companies sensitive to volatility in periods of shock. It is also worth mentioning the negative relation in some scenarios analyzed for the lag $\mathrm{t}-2$, which may indicate that excess cash for longer periods is not well evaluated by the market.

Changes in indebtedness represent a threat to future returns. Indebted companies are more likely to experience liquidity problems or the simple fact that these entities have their risk priced higher. This hypothesis is confirmed by observing the relation between the signal and the return, 
with a significant and negative coefficient for sensitive companies. Shock periods do not seem to alter this effect.

The fundamentalist gross margin signal has more significant results in the group of companies not sensitive to IVol-BR. The negative relation with the returns in the different lags is not altered by volatility shock scenarios for this group of companies.

In the group of companies in the study, the receivables signal has a negative relation with lagged returns, even so, in volatility scenarios the coefficient is close to zero. When looking at the two groups, of sensitive companies or not, the evidence of relation with returns is weak only in the group of sensitive companies.

Regarding CAPEX, there is statistical significance only in the interaction with shock dummies, with a positive sign for non-sensitive entities and a negative sign for sensitive ones. The results show that the relation of such a fundamentalist signal depends on the volatility and sensitivity characteristics of IVol-BR.

For the effective tax rate and inventory signals, the results are not very significant. The ability of the effective tax rate signal to explain returns depends on whether the company is sensitive to volatility, the relation being significant and negative only for the group of sensitive companies. The inventories signal only shows a significant relation for the group of non-sensitive companies. For the sensitive group, a significant relation is only seen in the interaction with the shock dummy, with a negative sign, thus guiding that in high volatility scenarios, for this group, an increase in inventories is seen as bad news for future returns.

Based on what has been detailed, it is clear that the usefulness of fundamental analysis is altered by at least two factors: the first according to the sensitivity of the asset to the measure of risk and the second refers to the contemporary stage of volatility market share. After having this knowledge, it is important to point out that the user of fundamentalist signals must first find out about the current stage of market volatility and the factors that can increase or decrease such volatility in the short term, before proceeding with the use of fundamental analysis to generate its opinion on the future movement of the entity's prices. In addition to mapping the stage of market volatility, attention should also be paid to the sensitivity level of the asset under analysis.

\section{REFERENCES}

Abarbanell, Jeffery S., \& Bushee, B. J. (1998). Abnormal Returns to a Fundamental Analysis Strategy. The Accounting Review, 73(1), 19-45. http://www.jstor.org/stable/248340

Abarbanell, Jeffrey S., \& Bushee, B. J. (1997). Fundamental Analysis, Future Earnings, and Stock Prices. Journal of Accounting Research, 35(1), 1-24. https://dx.doi.org/10.2307/2491464

Anderson, M., Hyun, S., \& Yu, D. (2017). Fundamental analysis conditioned on firm life cycle. Working paper. University of Calgary.

Anderson, M., Banker, R., Huang, R., \& Janakiraman, S. (2007). Cost behavior and fundamental analysis of SG\&A costs. Journal of Accounting, Auditing \& Finance, 22(1), 1-28.

Astorino, E. S., Chague, F., Giovannetti, B., \& Silva, M. E. D. (2017). Variance premium and implied volatility in a low-liquidity option market. Revista Brasileira de Economia, 71(1), 3-28.

Ball, R., Gerakos, J., Linnainmaa, J. T., \& Nikolaev, V. V. (2016). Accruals, Cash Flows, and Operating Profitability in the Cross Section of Stock Returns. Journal of Financial Economics, 121(1):28-45. https://doi.org/10.1016/j.jfineco.2016.03.002 
BBR

17

638

Barak, S, Azadeh A. \& Ortobelli S. (2017) Fusion of multiple diverse predictors in stock market. Information Fusion, 36, 90-102. https://doi.org/10.1016/j.inffus.2016.11.006

Bastos, D. D., Nakamura, W. T., David, M., \& Rotta, U. A. S. (2009). A relação entre o retorno das açóes e as métricas de desempenho: evidências empíricas para as companhias abertas no brasil. REGE Revista de Gestâo, 16(3), 65-79. https://doi.org/10.5700/issn.2177-8736.rege.2009.36678

Boyer, B., Mitton, T., \& Vorkink, K. (2010). Expected Idiosyncratic Skewness. The Review of Financial Studies, 23(1), 169-202. https://doi.org/10.1093/rfs/hhp041

Copeland, T. E., Koller, T., \& Murrin, J. (2006). Avaliação de empresas-valuation: calculando e gerenciando o valor das empresas. Pearson Makron Books.

Deloof, M. (2003). Does Working Capital Management Affect Profitability of Belgian Firms? Journal of Business Finance and Accounting, 30(3-4), 573-588. https://doi.org/10.1111/1468-5957.00008

Desai, M. A., \& Dharmapala, D. (2009). Corporate tax avoidance and firm value. The review of Economics and Statistics, 91(3), 537-546.

Figliori, B., Lima, F. G., Pimenta,T. J., \& Pereira, L. C. J. (2015). Modelos fundamentalista e de risco aplicados ao Índice Brasileiro de Sustentabilidade Empresarial: uma abordagem pela análise envoltória de dados. Práticas em Contabilidade e Gestão, 3(1), 74-103. http://editorarevistas. mackenzie.br/index.php/pcg/article/view/9834

Gujarati, D. N. (2009). Basic econometrics. Tata McGraw-Hill Education.

Haryanto, T., \& Retnaningrum, M. (2019). Pengaruh capital expenditure terhadap revenue, number of customer, profit dan return on investment (studi pada perusahaan telekomunikasi yang terdaftar di bei periode 2009-2016). JMM Unram-Unram Management Review, 8(3), 270-279.

Kimmel, P. D., Weygandt, J. J., \& Kieso, D. E. (2005). Financial Accounting: Tools for Business Decision Making Third Edition (3th edition). Wiley.

Kuhnen, C. M. (2015). Asymmetric learning from financial information. The Journal of Finance, 70(5), 2029-2062.

Lambert, S. L. (2011). Fundamental Signals, Future Earnings And Security Analysts' Efficient Use Of Fundamental Signals During 1991 Through 2008. [Doctoral dissertation, The University of Texas]. https://uta-ir.tdl.org/uta-ir/handle/10106/5838

Malacrida, M. J. C. (2009). A relevância do lucro líquido versus fluxo de caixa operacional para $o$ mercado de açóes brasileiro (Doctoral dissertation, Universidade de São Paulo). https://doi. org/10.11606/T.12.2009.tde-27032009-121238

Malta, T. L., \& Camargos, M. A. (2016). Variáveis da análise fundamentalista e dinâmica e o retorno acionário de empresas brasileiras entre 2007 e 2014. REGE - Revista de Gestão, 23(1), 52-62. https://doi.org/10.1016/j.rege.2015.09.001

Matarazzo, D. C. (2010). Dante Carmine. Análise financeira de balanços: abordagem gerencial. 7th ed. São Paulo: Atlas.

Mohanram, P. S. (2005). Separating winners from losers among lowbook-to-market stocks using financial statement analysis. Review of accounting studies, 10(2-3), 133-170.

Nti, I. K., Adekoya, A. F., \& Weyori, B. A. (2019). A systematic review of fundamental and technical analysis of stock market predictions. Artificial Intelligence Review, 53, 3007-3057. https://doi. org/10.1007/s10462-019-09754-z 
Oliveira, R. S. de, Silva, A. F., Hernandes, J., M., \& Ribeiro, K. C. de S. (2019). Análise do impacto de recebíveis nos indicadores econômico-financeiro das organizaçóes. Anais do Congresso Brasileiro de Custos. Curitiba, Brasil, XXVI. https://anaiscbc.emnuvens.com.br/anais/article/view/4515

Perobelli, F. F. C., Famá, R., \& Sacramento, L. C. (2016). Relaçôes entre Liquidez e Retorno nas Dimensões Contábil e de Mercado no Brasil. Revista Contabilidade \& Finanças, 27(71), 259-272. https://doi.org/10.1590/1808-057x201601530

Soares, E. R., \& Galdi, F. C. (2011). Relação dos modelos DuPont com o retorno das ações no mercado brasileiro. Revista Contabilidade \& Finanças, 22(57), 279-298. https://doi.org/10.1590/ S1519-70772011000300004.

Thomas, J. K., \& Zhang, H. (2002). Inventory changes and future returns. Review of Accounting Studies, 7(2-3), 163-187.

Tsai MF, Wang C-J (2017) On the risk prediction and analysis of soft information in fnance reports. European Journal of Operational Research, 257(1), 243-250. https://doi.org/10.1016/j. ejor.2016.06.069

Vicente, J. V. M., \& Guedes, T. de S. (2010). Does implied volatility contain information about future volatility? Evidence from the Petrobras options market. Brazilian Business Review, 7(1), 42-58.

Whaley, R. E. (2000). The investor fear gauge. The Journal of Portfolio Management, 26(3), 12-17.

Wahab, N. S. A., \& Holland, K. (2012). Tax planning, corporate governance and equity value. The British Accounting Review, 44(2), 111-124.

Wahab, S., Teitel, K., \& Morzuch, B. (2017). How Analysts and Whisperers Use Fundamental Accounting Signals to Make Quarterly EPS Forecasts. Journal of Accounting, Auditing \& Finance, 32(3), 401-422. https://doi.org/10.1177/0148558X15613040

Wanderley Villaschi, A., Caio Galdi, F., \& Neris Nossa, S. (2011). análise fundamentalista para seleção de uma carteira de investimento em açóes com baixa razão book-to-market. BASE-Revista de Administração e Contabilidade da Unisinos, 8(4), 325-337. https://doi.org/10.4013/4426

Yan, X., \& Zheng, L. (2017). Fundamental analysis and the cross-section of stock returns: A datamining approach. The Review of Financial Studies, 30(4), 1382-1423.

Zhang, X., Zhang, Y., Wang, S., Yao, Y., Fang, B., \& Philip, S. Y. (2018). Improving stock market prediction via heterogeneous information fusion. Knowledge-Based Systems, 143, 236-247.

\section{AUTHOR'S CONTRIBUTION}

First author contributes to the writing of the text, collection, treatment, obtaining econometric models and data analysis. Second author and third author guided the conduct of the research, reviewed the work throughout its development and collaborated with the collection and treatment of data.

\section{CONFLICTS OF INTEREST}

The authors declare that there is no conflict of interest in relation to the content exposed in the work. 